\title{
Gamification in programming - A short introductory session in programming with online games
}

\author{
É. ÁDÁMKÓ
}

University of Debrecen, Faculty of Engineering, Institute of Industrial Process Management, Department of Basic Technical Studies, adamko.eva@eng.unideb.hu

Abstract. Nowadays computer science is a diversified discipline with a wide range of interdisciplinary applications. Because of that, teachers at primary or high schools unavoidably face the following problem: What are the most useful fields, topics and applications of computer science and programming, and how can we teach them to be motivating enough for a student from the $Z$ generation. In this paper we give a possible answer for the question above by presenting a short introductory session in programming for students in primary and high school. Our primary aim with the above session is to motivate students to continue their studies in engineering higher education. We also present our experiences about two experimental classes here.

\section{Introduction}

In this paper the applied methods and experiences of a short introductory session in the field of computer programming is presented. The above study has been realised at the Faculty of Engineering of the University of Debrecen in the frame of the "Debrecen Venture Catapult" project by the research group named "Developing skills for engineering and innovation". The aim of the research group was to give an insight into different engineering field sand to motivate primary and high school students this way to continue their studies in engineering higher education. Two groups of primary school students took part in our experiments. The aim of the study was to determine the minimum age above which our educational method is applicable. During the session students got a basic introduction to programming concepts as object, function, comment, or control structures. An online game was chosen for the realisation of our teaching method, in accordance with the special needs of generation $\mathrm{Z}$.

\section{Test groups}

The experiments were performed involving two student groups at the Primary School "Árpád Vezér" in Debrecen, which is the second largest city in Hungary. At the above school the results of students are outstanding. The average grades of students are 4.8 and 4.2 in mathematics and informatics respectively. The teacher of both groups was the same person also in informatics and mathematics, and all of the students have come from families where both parents have university degree. Table 1 and 2 show the basic characteristics of the groups. 


\section{Group 1.}

\begin{tabular}{ll}
\hline $\begin{array}{l}\text { Time of the class } \\
\text { Grade }\end{array}$ & May (End of the school year) \\
$\begin{array}{l}\text { Number of students } \\
\text { Girls }\end{array}$ & 14 \\
Boys & 6 \\
Average grade in & 4.47 \\
$\begin{array}{l}\text { Mathematics } \\
\text { Average grade in }\end{array}$ & 4.73 \\
$\begin{array}{l}\text { Informatics } \\
\text { Programming classes } \\
\text { during the class year due } \\
\text { to national curriculum }\end{array}$ & 10
\end{tabular}

Table 1. Properties of group 1

Group 2.

\begin{tabular}{ll}
\hline $\begin{array}{l}\text { Time of the class } \\
\text { Grade }\end{array}$ & October (Start of the school year) \\
$\begin{array}{l}\text { Number of students } \\
\text { Girls }\end{array}$ & 12 \\
Boys & 5 \\
Average grade in & 4.23 \\
$\begin{array}{l}\text { Mathematics } \\
\text { Average grade in }\end{array}$ & 4.69 \\
$\begin{array}{l}\text { Informatics } \\
\text { Programming classes } \\
\text { during the class year due } \\
\text { to national curriculum }\end{array}$ & 8
\end{tabular}

Table 2. Properties of group 2

\section{Subject methodology relations}

The main aim of the sessions is to raise the interest of students in the field of computer programming. Since several basic abilities are needed for a student to be able to write a right and workable program the effective teaching of programming is a great challenge, especially with a student in her/his early age. Another problem is that the effective teaching methods is completely different for generation $\mathrm{Z}$ 
and for the generations Y, X and earlier ones. Members of the so called "Digital Natives" were born into the Internet-connected world, and they differ in many ways from the other generations. The most important characteristics of their learning style are listed below:

- Prefer to learn by doing instead of being told.

- Prefer activities as a part of a team instead of working alone.

- They need instant feedback, gratification, positive reinforcement, rewards.

- They have shorter attention span.

- They like taking advantage of shortcuts.

Our recommendations about the effective learning of programming are as follows:

- Gamification:

"is a set of activities and processes to solve problems by using or applying the characteristics of game elements." [Song, Kibong, et al. 2018]

- Problem-based

learning

"is a teaching method in which complex real-world problems are used as the vehicle to promote student learning of concepts and principles as opposed to direct presentation of facts and concepts. In addition to course content, PBL can promote the development of critical thinking skills, problem-solving abilities, and communication skills. It can also provide opportunities for working in groups, finding and evaluating research materials, and life-long learning" [Duch, B. J., Groh, S. E, \& Allen, D. E. 2001]

- Live

coding

"the process of designing and implementing a [coding] project in front of class during lecture period" [Rubin, Marc J. 2013]

Considering the characteristics of generation $\mathrm{Z}$, and the recommendation of the related publications above, the gamification as a teaching method was chosen by the author. After that, a game was chosen, which is available online, challenging enough for students and promises useful knowledge to them. During the selection, the author has tried many online games, but most of them were available only in English and they were for teaching script languages like Coffee Srcipt, JavaScript, Ruby, etc. The author's original aim was to teach $\mathrm{C}$ or Java to his classes, but unfortunately none of these programming languages can be learned by applying an online game in Hungarian. So finally, Code Combat with Python has been chosen by the author.

\section{Introduction of Code Combat}

The Code Combat is an online game, which helps to learn two programming languages - JavaScript or Phyton -, it recommended for children over 10 years. Through the game, we control a hero with writing real program code, who has to solve different tasks, for example find a way to escape from the ogres. There are extra packages of the game in which we can learn HTML or CSS. Code Combat provides a platform on which student scan learn programming easily while they are playing an interesting game. The game provides a very handful toolset to the beginner programmers, who are able to write a clean and right code from the first line, they ever code. While they are writing the code, the game immediately interacts with error notes, help messages and we can try the operation of the 
process in any time. So, students design, write and debug program code from the very first level. The user interface of the game gives an opportunity for the teachers to create their own classes, and in these classes, we can follow the progression of each student individually. The game provides many helps for the students in the way of giving course guides, and ready to use teaching materials. The next two figures show the starting page of Code Combat and also one level of it.

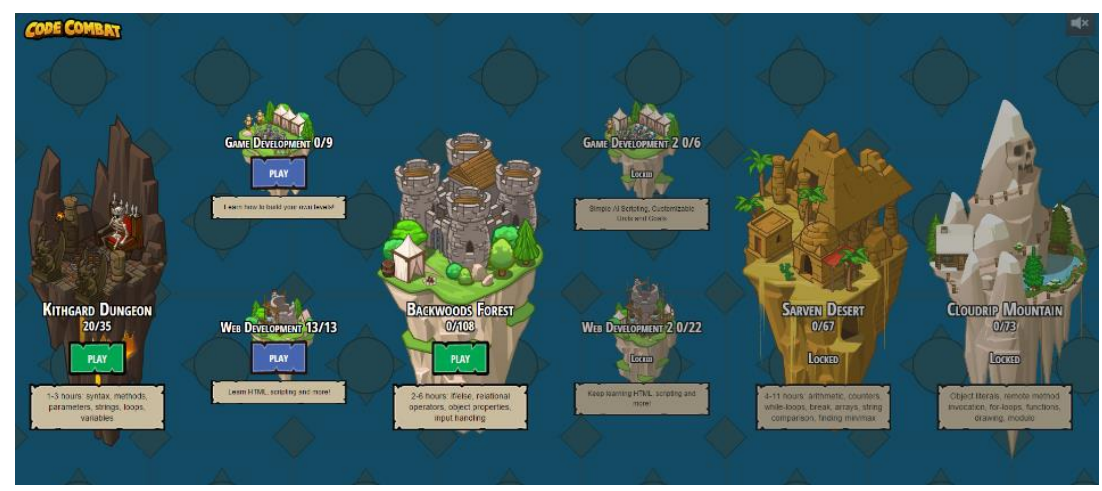

Figure 1. Starting Page of Code Combat

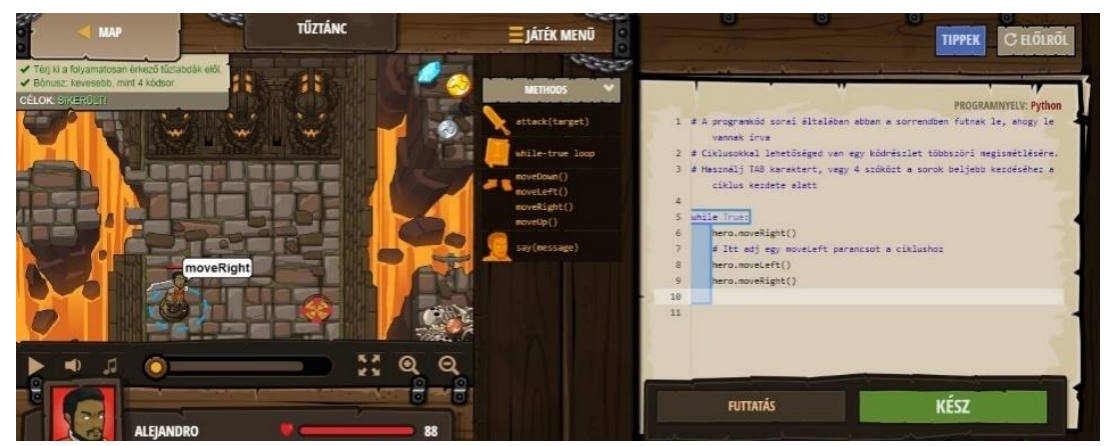

Figure 2. One of the levels of Code Combat

\section{Structure of the session}

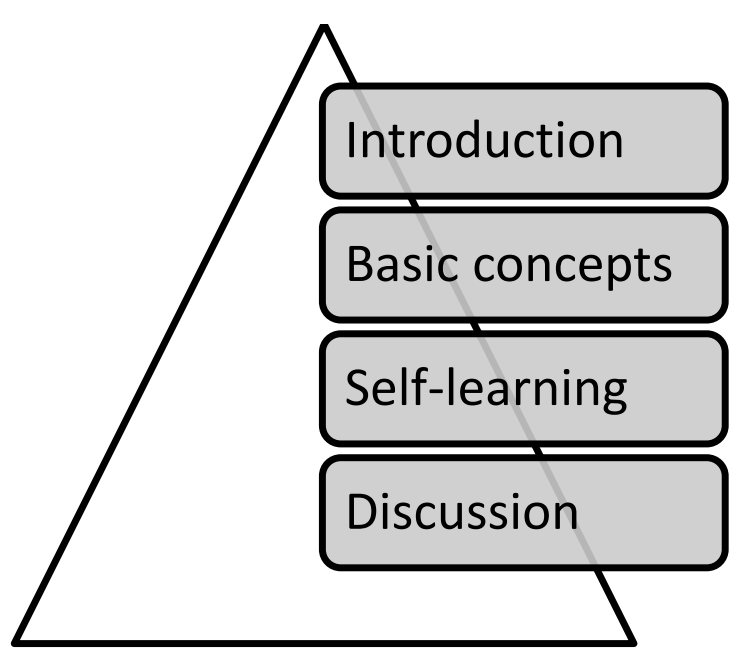

Figure 3. Structure of the session 
The session starts with a short introduction, during this part both the students both the lecturer learns some information about each other, and the lecturer explains the rules of the Code Combat and how to use it. After everybody registered to the right class, we go further on the basic concepts. The Code Combat is a game, where the gamer must create program code from the first level but writing program code without any help is very hard. Although the game helps in many ways, it seems important defining the very basics of programming, because the programming is a very complicated task as the following definition states:

Programming - a process involving: analysis and understanding of problems; identifying and evaluating possible solutions; generating algorithms; implementing solutions in the code of a particular programming language; testing and debugging, in order to formulate solutions into executable computer programs. [Webb, Mary, et al. 2017]

That is why we discuss the following concepts: programming language, program code, object, comment, control statements like loops and conditional statements for example if-else. During the game the Code Combat will help to understand these concepts as well but, because this session is given students in a very early age, it seems better to multiple the source of information. After this 10-15minuteintroductory part the students start to play, they have 40-50 minutes. Usually the students are motivated and excited about the opportunity to play a new game, and most of them feel the task is challenging. During this so-called self-learning part of the session the students can get help, if they needed. At the end of the session in a few minutes, the student can share their opinion about the session. In the following tables the summarized results of both groups are presented.

Group 1.

\begin{tabular}{ll}
\hline Total level & 17 \\
Total playtime & $31 \mathrm{~min}$ \\
Average level & 9,93 levels \\
Average playtime & $25,4 \mathrm{~min}$ \\
Average playtime/level & $2,56 \mathrm{~min}$ \\
Boys average level & 9,66 levels \\
Boys average playtime & $22,66 \mathrm{~min}$ \\
Boys average playtime/level & 2,34 levels \\
Girls average level & 10,11 levels \\
Girls average playtime & $27,22 \mathrm{~min}$ \\
Girls average playtime/level & $2,69 \mathrm{~min}$
\end{tabular}

Table 3. Results of group 1. 


\section{Group 2.}

\begin{tabular}{ll}
\hline Total level & 16 \\
Total playtime & $60 \mathrm{~min}$ \\
Average level & 9,77 levels \\
Average playtime & $44,38 \mathrm{~min}$ \\
Average playtime/level & $4,54 \mathrm{~min}$ \\
Boys average level & 11,86 levels \\
Boys average playtime & $46,86 \mathrm{~min}$ \\
Boys average playtime/level & 3,95 levels \\
Girls average level & 7,33 levels \\
Girls average playtime & $41,5 \mathrm{~min}$ \\
Girls average playtime/level & $5,66 \mathrm{~min}$
\end{tabular}

Table 4. Results of group 2.

New concept on the levels

\begin{tabular}{ll}
\hline $1-2$ & Basic syntax \\
$3-4$ & Arguments \\
5 & Texts \\
$6-7$ & Reading the docs \\
$8-13$ & While loop \\
$14-17$ & Variables
\end{tabular}

\section{Conclusion}

Teachers and students were satisfied after the sessions, it was challenging, motivating and entertaining to them, based on the shared opinion. The Code Combat was easy to use, despite the fact that the students have no previous experiences and knowledge about programming at all. Other conclusions cannot be deducted, because of the low amount of data.

\section{Acknowledgements}

A publikáció elkészítését az EFOP-3.6.1-16-2016-00022 számú project támogatta. A project az Európai Uniótámogatásával, az Európai Szociális Alap társfinanszírozásával valósult meg. 


\section{References}

[1] M. Webb et al. (2017) Computer science in K-12 school curricula of the 2lst century: Why, what and when?. Education and Information Technologies 22.2 445-468.

[2] D. Rothman (2016) A Tsunami of learners called Generation Z. URL: http://www. mdle. net/JoumaFA_Tsunami_of_Learners_Called_Generation_Z.pdf

[3] C. Seemiller - G. Meghan (2016) Generation Z goes to college. John Wiley \& Sons.

[4] T. Jenkins (2002) On the difficulty of learning to program. In: Proceedings of the 3rd Annual Conference of the LTSN Centre for Information and Computer Sciences. Vol. 4. No. 2002.

[5] D. Zhao et al. (2018) A Large-scale Pilot Study on Game-based Learning and Blended Learning Methodologies in Undergraduate Programming Courses. In: EDULEARN Conference, Palma de Mallorca, Spain.

[6] J. Hromkovic et al. (2017) Algorithmic thinking from the start. Bulletin of EATCS 1.121

[7] J. M. Wing (2006) Computational thinking. Communications of the ACM. 49.3 33-35.

[8] K. Song et al. (2018) Gamification in Learning and Education.

[9] B. J. Duch - S. E. Groh - D. E. Allen (Eds.). (2001) The power of problem-based learning. Sterling, VA: Stylus.

[10] M. J. Rubin (2013) The effectiveness of live-coding to teach introductory programming. In: Proceeding of the 44th ACM technical symposium on Computer science education. ACM. 